\title{
First occurrence of Dioclea ruddiae Maxwell (Leguminosae) in Brazil
}

\author{
Andréia Silva Flores ${ }^{1,3}$ and Rodrigo Schütz Rodrigues ${ }^{2}$
}

Received: 23.05.2017; accepted: 17.10.2017

\begin{abstract}
First occurrence of Dioclea ruddiae Maxwell (Leguminosae) in Brazil). Dioclea ruddiae (Leguminosae, Papilionoideae) is recorded for the first time in Brazil. Specimens were collected in the Serra do Tepequém, a tepui in the State of Roraima near the border with Venezuela. This study expands the distribution range of Dioclea ruddiae in the region of the Guiana Shield, where this species is probably endemic.

Keywords: Diocleinae, Guiana Shield, new record, Roraima, Serra do Tepequém, Tepui

RESUMO - (Primeira ocorrência de Dioclea ruddiae Maxwell (Leguminosae) no Brasil). Dioclea ruddiae (Leguminosae, Papilionoideae) é registrada pela primeira vez no Brasil. Espécimes foram coletados na Serra do Tepequém, um tepui no Estado de Roraima, próximo à fronteira com a Venezuela. Deste modo, este estudo amplia a distribuição de Dioclea ruddiae na região do Escudo das Guianas, na qual é provavelmente endêmica.

Palavras-chave: Diocleinae, Escudo das Guianas, nova ocorrência, Roraima, Serra do Tepequém, Tepui
\end{abstract}

\section{Introduction}

Dioclea Kunth is one of 13 genera of Diocleinae, a subtribe of Phaseoleae (Leguminosae, Papilionoideae) of vines or lianas with trifoliolate leaves and nodose pseudoracemes (Queiroz et al. 2003, Schrire 2005). Traditionally, Dioclea has comprised ca. 40 species, mostly in Brazil (Schrire 2005). However, recent phylogenetic analysis of Diocleinae has indicated that Dioclea species form a clade with Cleobulia Mart. ex Benth., Cymbosema Benth., and Macropsychanthus Harms ex K. Schumann \& Lauterbach, recognized by multi-flowered inflorescences with a woody rachis, bicallose and auriculate standard petal, lignescent fruits and seeds mostly with a linear hilum (Queiroz et al. 2015).

In Brazil, Dioclea is represented by 32 species, of which 15 are endemic to the country (BFG 2015). In the north region, 23 species occur mainly in Amazon rainforests and particularly in Roraima State BFG (2015) recorded four species, D. apurensis Kunth, D. guianensis Benth., D. macrantha Huber, and D. reflexa Hook.f.
The Guiana Shield comprises a northeastern region of South America between the Amazonas, Negro and Orinoco Rivers (Funk et al. 2007). This region extends through Colombia, Venezuela, Guiana, Suriname, French Guiana and extreme north of Brazil and is distinguished by more than 50 tabletop mountains, known as tepuis, which show high levels of endemism (Huber 1995). Among these mountains there can be highlighted in Brazil the Serra do Aracá and Pico da Neblina in the Amazonas State and Monte Roraima and Serra do Caburaí in the Roraima State (Prance \& Johnson 1992; Coelho et al. 2015). In these mountains, recent botanical expeditions have led to a significant increase in the number of new records for the flora of Brazil (Rodrigues \& Flores 2010, BarbosaSilva et al. 2016, Costa 2017).

In addition, in northern Roraima there is a low tepui, the Serra of Tepequém, located about $30 \mathrm{~km}$ north of the Ilha de Maracá ecological station boundary (Milliken \& Ratter 1998). Since studies on the flora of the Serra do Tepequém are not available, in the last years we carried out field expeditions to

1. Instituto de Amparo à Ciência, Tecnologia e Inovação do Estado de Roraima, Museu Integrado de Roraima, Herbário MIRR, Avenida Brigadeiro Eduardo Gomes, 1.128, 69330-640 Boa Vista, RR, Brasil

2. Universidade Federal de Roraima, Centro de Estudos da Biodiversidade, Avenida Capitão Ene Garcez, 2413, 69310-000 Boa Vista, RR, Brasil

3. Corresponding author: andreiasflores@gmail.com 
this site focusing on Leguminosae taxa. As a result of these efforts, we have found a new record of Dioclea for Brazil, which is described and illustrated herein.

\section{Materials and methods}

The Serra do Tepequém is located in the municipality of Amajarí, ca. $200 \mathrm{~km}$ by road from Boa Vista, the capital of the Brazilian State of Roraima. It is a tepui with up to $1000 \mathrm{~m}$ high, consisting of a single massif about $70 \mathrm{~km}^{2}$ whose sandstone sedimentary rocks dating back to Precambrian (Reis \& Carvalho 1996).

Botanical expeditions to the Serra do Tepequém were monthly undertaken between 2008 and 2010 to examine its different herbaceous, shrub and forest vegetation types (Barbosa 1992). A morphological analysis was carried on collections deposited in MIRR herbarium (Thiers 2017). Specimens were identified using specialized literature (Maxwell 1988, 1999) and available images of type specimens from F, US, GH, RB, S, US and VEN herbaria (Thiers 2017). Geographic distribution information of the analyzed species was obtained from its protologues (Maxwell 1988) and Maxwell (1999) supplemented with data from US, F, and MO herbaria provided that they have been identified by R. H. Maxwell. Localities of specimens were georeferenced primarily using label data which were checked with Google Earth and the Global Biodiversity Information Facility (GBIF 2017). A map was generated using DIVA-GIS software (Hijmans et al. 2012).

\section{Results and Discussion}

Dioclea ruddiae R.H. Maxwell, Ann. Missouri Bot. Gard. 75:730. 1988. Type:VENEZUELA.AMAZONAS: CerroHuachamacari, Río Cunucunuma, occasional in slope forest near Camp 2, 16-XII-1950, B. Maguire et al. 29930 (holotype US!; isotypes F!, GH!, HUEFS, IAN, K, MO, NY, P, RB!, S!, U, US!, VEN!).

Figures 1-2

Woody vines; stipules not extending below attachment. Leaflets elliptic, subcoriaceous, pubescent, $12-21 \times 6.8-9 \mathrm{~cm}$. Inflorescence axillary, flowers with petals glabrous, the keel petals asymmetrically oblong; anthers 10, monomorphic. Legume 2-seeded, turgid, oblong, glabrescent, $8-10.5 \times 3.5-4.3 \times 2.6-3 \mathrm{~cm}$, indehiscent, with indistinct sutural ribs, the beak upcurved. Seeds compressed, elliptic, overgrown, 4-4.5 $\times 2.8-3.2 \mathrm{~mm}$, hilum oblong, encircling half of seed circumference.
Material examined: BRAZIL. RoraImA: Amajari, Serra do Tepequém, platô, Igarapé do Paiva, junto à ponte, 034ㄴ $21.0^{\prime \prime} \mathrm{N}, 61^{\circ} 43^{\prime} 18.0^{\prime \prime} \mathrm{W}, 605 \mathrm{~m}$, 24-IV-2008, fr., R. Schütz Rodrigues et al. 1931 (MIRR); id, R. Schütz Rodrigues et al. 1947 (MIRR).

Dioclea ruddiae is most similar to D. macrocarpa Huber, as both have flowers with monomorphic anthers, indehiscent fruits, and overgrown seeds with an oblong hilum (Maxwell 1988, 1999, Queiroz et al. 2003). On the other hand, D. macrocarpa has papyraceous leaflets glabrous or glabrescent beneath; inflorescences frequently cauliflorous and flat fruits ca. $1 \mathrm{~cm}$ thick (Maxwell 1988). In contrast, D. ruddiae has subcoriaceous leaflets pubescent beneath, axillary inflorescences and turgid fruits ca. $3 \mathrm{~cm}$ thick (figure $1 \mathrm{a}-\mathrm{b}$ ). In addition, turgid fruits of $D$. ruddiae promptly distinguish it from the other four species of Dioclea previously recorded in the State of Roraima (BFG 2015) that possess compressed legumes.

In Roraima State, specimens were collected in flower and fruit in April. In Venezuela, according to Maxwell (1988), specimens flowered from December through June and bore fruits from April to May.

Dioclea ruddiae was earlier known as endemic to Venezuela (Maxwell, 1988) from a few localities in the States of Amazonas and Bolívar, occurring in savannas or humid forests in mountains from 800 to $1600 \mathrm{~m}$ altitude (Maxwell 1999). This species is reported here for the first time from Brazil, in montane riverine forest edges, at $605 \mathrm{~m}$ altitude, in Serra do Tepequém (figure $1 \mathrm{c}-\mathrm{d}$ ). The previously known populations of $D$. ruddiae closer to the Serra do Tepequém are $120 \mathrm{~km}$ northeast away in Bolivar State and $330 \mathrm{~km}$ west in the State of Amazonas, both in Venezuela (figure 2).

Most specimens of Venezuelan populations of D. ruddiae have been collected at or near protected areas in both States of Amazonas and Bolivar such as Duida-Marahuaca, Parima-Tapirapeco and Canaima national parks (Maxwell 1988, 1999). On the other hand, the Serra do Tepequém has a long history of environmental degradation due to mining activities (Barbosa 1992). As this tepui unfortunately remains an unprotected area, it has continuously been subject to the disorganized human settlement, deforestation and tourism activities, which might threat the existence of the only known Brazilian population of D. ruddiae.

In short, this study expands the distribution range of $D$. ruddiae within the Guiana Shield where it appears to be endemic. It also emphasizes the need of more botanical collection efforts in the Brazilian 

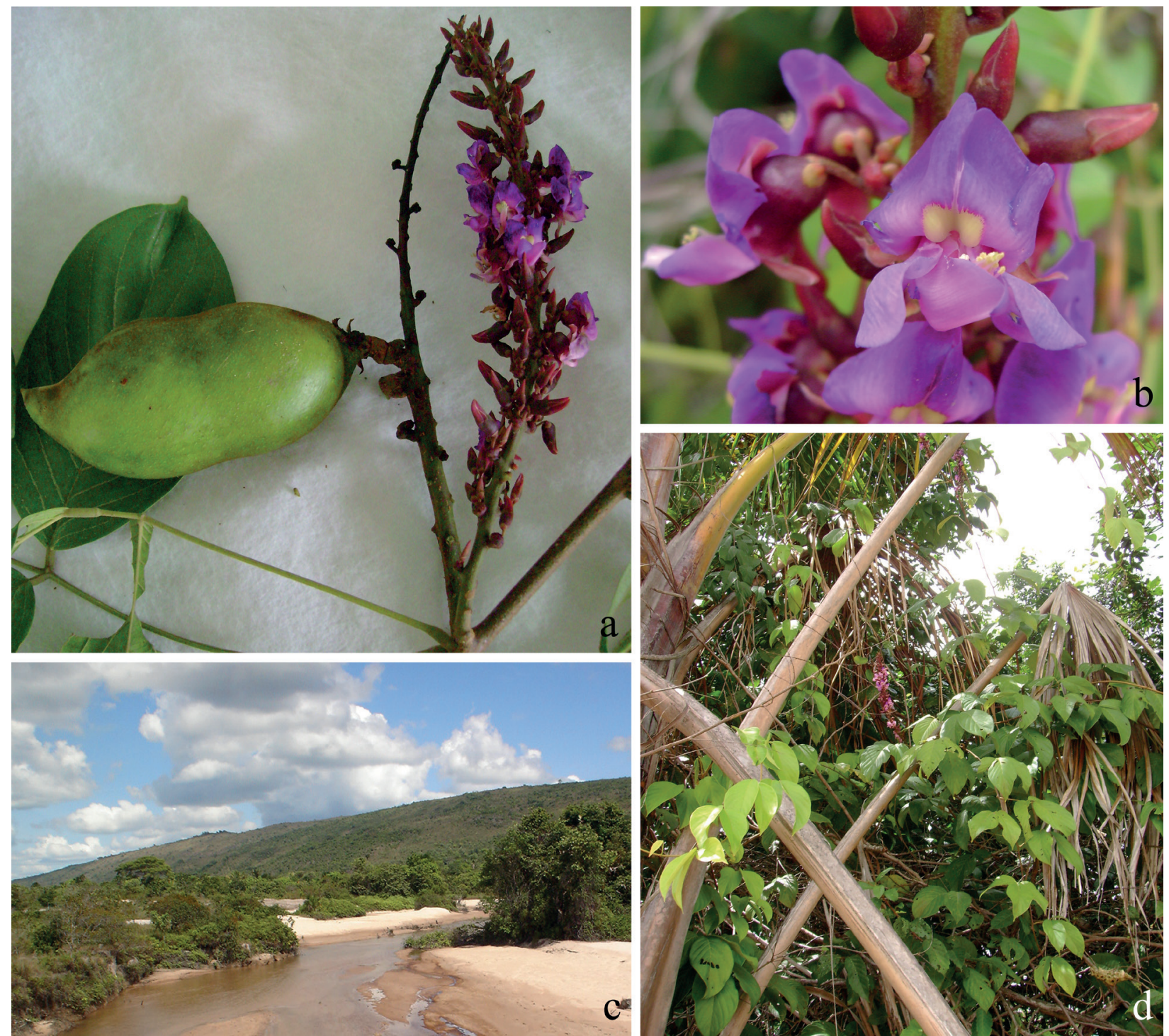

Figure 1. Habitat and morphology of Dioclea ruddiae. a. Branch with flowers and a turgid two-seeded legume. b. Detail of an inflorescence. c. Locality where $D$. ruddiae was collected in the Serra do Tepequém, Roraima State, Brazil. d. Specimen growing on riverine forest edge (figures a-b and d by C.S. Costa and figure $\mathrm{c}$ by R.S. Rodrigues).

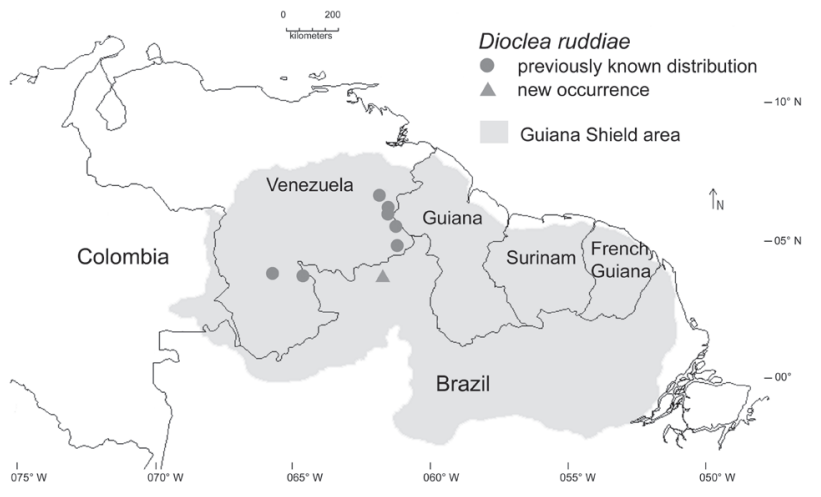

Figure 2. Geographical distribution of Dioclea ruddiae with emphasis on the new occurrence in Brazil. The Guiana Shield area according to Funk et al. (2007).
Guiana Shield, which is relatively poorly known in relation to neighbor areas.

\section{Acknowledgements}

We are grateful to Christiane Silva da Costa for permitting the publication of her photographs, staff of MIRR herbarium (Christiane Silva da Costa, Octaviano Grigio Jr., Cice Batalha Maduro, Anderson Otaviano, and Roberto Serafim) for support in field activities, and SESC Roraima for hosting us at the Estância Ecológica Sesc Tepequém; two anonymous reviewers are acknowledged for their constructive comments. ASF was supported by a CNPq/FEMACT DCR grant (proc. 508/2006-01) and RSR by CNPq (proc. 475283/2007-4). 


\section{Literature cited}

Barbosa, R.I. 1992. Um tepui no ritmo da destruição em Roraima. Ciência Hoje 14: 94-96.

Barbosa-Silva, R.G., Labiak, P.H., Gil, A.S.B., Goldenberg, R., Michelangeli, F.A., Martinelli, G., Coelho, M.A.N., Zappi, D.C. \& Forzza, R.C. 2016. Over the hills and far away: New plant records for the Guayana Shield in Brazil. Brittonia 68: 397-408.

BFG. 2015. Growing knowledge: An overview of seed plant diversity in Brazil. Rodriguésia 55: 1085-1113.

Coelho, M.A.N., Costa, D.P., Martinelli, G., Moraes, M.A., Forzza, R.C. \& Azoury, R. 2015. Expedições às montanhas da Amazônia. Rio de Janeiro: Jardim Botânico do Rio de Janeiro/A. Jakobsson Estúdio.

Costa, D.P. 2017. Bryophyte results from a botanical expedition to Serra do Aracá, State Amazonas, Brazil: diversity, distribution, and endemism. The Bryologist 120:45-50.

Funk, V., Hollowell, T., Berry, P., Kelloff, C.\& Alexander, N.S. 2007. Checklist of the plants of the Guiana Shield (Venezuela: Amazonas, Bolivar, Delta Amacuro; Guyana, Surinam, French Guiana). Contributions from the United States National Herbarium 55: 1-584.

GBIF (Global Biodiversity Information Facility). 2017. Global Biodiversity Information Facility. Free and Open Access to Biodiversity Data. Available in http://www. gbif.org/ (access in 15-V-2017).

Hijmans, R.J, Guarino, L. \& Mathur, P. 2012. DIVA-GIS manual. University of California Davis. Version 7.5. Available in http://www.diva-gis.org (access in 10-II-2017).

Huber, O. 1995. Vegetation. In: P.E. Berry, B.K. Holst \& K. Yatskievych (eds.). Flora of the Venezuelan Guyana, Volume 1. Missouri Botanical Garden Press, St. Louis, pp. 97-160.

Maxwell, R.H. 1988. A new species of Dioclea Kunth (Diocleinae, Fabaceae) from the Venezuelan Guayana. Annals of the Missouri Botanical Garden 75: 730-732.
Maxwell, R.H. 1999. Dioclea. In: P.E. Berry, K. Yatskievych \& B.K. Holst (eds.). Flora of the Venezuelan Guyana, Volume 5. Missouri Botanical Garden Press, St. Louis, pp. 310-315.

Milliken, W. \& Ratter, J. (eds.). 1998. The Biodiversity \& Environment of an Amazonian rainforest. John Wiley \& Sons Ltd., Chichester.

Prance, G.T. \& Johnson, D.M. 1992. Plant collections from the plateau of Serra do Aracá (Amazonas, Brazil) and their phytogeographic affinities. Kew Bulletin 47: 1-24.

Queiroz, L.P., Fortunato, R.H. \& Giulietti, A.M. 2003. Phylogeny of the Diocleinae (Papilionoideae: Phaseoleae) based on morphological characters. In: B.B. Klitgaard \& A. Bruneau (eds.). Advances in Legume Systematics, Part 10. Royal Botanic Gardens Kew, Kew, pp. 303-324.

Queiroz, L.P., Pastore, J.F.B., Cardoso D., Snak, C., Lima, A.L.C., Gagnon, E., Vatanparast, M., Holland, A.E. \& Egan, A.N. 2015. A multilocus phylogenetic analysis reveals the monophyly of a recircumscribed papilionoid legume tribe Diocleae with well-supported generic relationships. Molecular Phylogenetics and Evolution 90: 1-19.

Reis, N.J. \& Carvalho, A.S. 1996. Coberturas sedimentares do Mesoproterozóico do estado de Roraima - avaliação e discussão de seu modo de ocorrência. Revista Brasileira de Geociências 26: 217-226.

Rodrigues, R.S. \& Flores, A.S. 2010. Novas ocorrências de Rapateaceae para o Brasil. Acta Botanica Brasilica 24: 1096-1099.

Schrire, B.D. 2005. Phaseoleae. In: G. Lewis, B. Schrire, B. Mackinder \& M. Lock (eds.). Legumes of the World. Royal Botanic Gardens Kew, Kew, pp. 393-431.

Thiers, B. 2017 [continuously updated]. Index Herbariorum: A global directory of public herbaria and associated staff. New York Botanical Garden's Virtual Herbarium. Available in http://sweetgum.nybg.org/science/ih (access in 11-III-2017). 